\title{
PENGEMBANGAN KARTU PINTAR FISIKA UNTUK MENINGKATKAN KETERAMPILAN PROSES SAINS KELAS XI PADA MATERI KESETIMBANGAN BENDA TEGAR
}

\author{
Misdawati ${ }^{*}$, Islahudin², M.Isnaini ${ }^{3}$ \\ ${ }^{1 *}$ Mahasiswa Sarjana Program Studi Pendidikan Fisika Universitas Muhammadiyah Mataram \\ ${ }^{283}$ Dosen Progran Studi Pendidikan Fisika Universitas Muhammadiyah Mataram \\ Corresponding author: \\ E-mail: (islahudin.ntb@gmail.com)
}

Diterima 25 Oktober 2017, Disetujui 8 November 2017

\section{ABSTRAK}

Tujuan dari penelitian ini untuk mengembangkan Kartu Pintar Fisika pada pokok pembahasan Kesetimbangan Benda Tegar, untuk meningkatkan keterampilan proses sains siswa. Penelitian ini menggunakan metode research and development ( $R$ \& $D)$. Populasi dalam penelitian ini adalah SMK Muhammadiyah Mataram dan Kelas XI.TSM sebagai sampel. Desain penelitian yang digunakan adalah pretest-postets desine. Model pengembangan yang digunakkan adalah Dick \& Cary yang terdiri dari 10 langkah yang harus diikuti untuk menghasilkan produk berupa Kartu Pintar Fisika. Data diperoleh melalui wawancara, lembar observasi, angket dan dokumentasi teknik analisis data yang digunakkan adalah deskriptif kualitatif untuk mengukur keterampilan proses sains siswa. Media Kartu Pintar Fisika yang dikembangkan juga memiliki kriteria yang sagat baik untuk meningkatka keterampilan proses sains dengan presentase sebesar $82 \%$ bila dibandingkan sebelum menggunakkan Kartu Pintar Fisika yaitu sebesar $63 \%$. Peningkatan keterampilan proses sains secara klasikal juga berada pada kriteria sedang dengan normalisasi gain sebesar 0,48 . Berdasarkan taraf kesalahan 5\% dari jumlah 17 siswa, maka diperoleh harga Chi Kuadrat Tabel =27,587. Ternyata harga Chi Kuadrat hitung lebih besar dari Harga Chi Kuadrat tabel yaitu (649>27,587). Berdasarkan hasil dari penelitian ini dapat disimpulkan bahwa Kartu Pintar Fisika dapat meningkatkan keterampilan proses sains kelas XI.TSM SMK Muhammadiyah Mataram Tahun Pelajaran 2016/2017.

Kata Kunci: Pengembangan Kartu Pintar Fisika, Keterampilan Proses Sains

\section{PENDAHULUAN}

Pendidikan adalah usaha sadar untuk menyiapkan peserta didik melalui kegiatan bimbingan, pengajaran, dan latihan bagi peranannya di masa yang akan datang (UUR.1. No. 2 TAHUN 1989 dalam Hamalik 2013). Keberhasilan pendidikan harus ditunjang oleh kemampuan guru dalam mengajar. Dalam proses pengajaran seorang guru harus mengembangkan strategi mengajar yang mengarah keaktifan optimal belajar siswa. Dengan demikian maka seorang guru tidak hanya dituntut untuk mampu menguasai materi pelajaran saja, akan tetapi juga dituntut untuk mampu mengembangkan metode-metode mengajar yang sesuai dengan tujuan pendidikan metode mengajar yang dimaksud agar siswa dapat dengan mudah memahami pelajaran yang diajarkan.

Pemilihan metode dan media yang tepat dapat menciptakan situasi belajar yang menyenangkan dan mendukung kelancaran proses pembelajaran sehingga siswa lebih termotivasi dalam belajar.
Pemilihan metode dan media
pembelajaran perlu memperhatikan
beberapa hal seperti materi yang

disampaikan, tujuannya, waktu yang tersedia, dan banyaknya siswa serta halhal yang berkaitan dengan proses pembelajaran. Guru harus menguasai bermacam-macam metode dan media pembelajaran sehingga guru tidak hanya menerapkan metode ceramah, karena metode ceramah guru masih sangat dominan dan siswa masih banyak menghafal materi yang diberikan sehingga menyebabkan siswa bosan dan tidak tertarik dengan pelajaran terutama pada mata pelajaran fisika.

Fisika merupakan salah satu mata pelajaran yang sangat penting diajarkan mulai dari tingkat Sekolah Dasar sampai Perguruan Tinggi. Sering dikatakan bahwa fisika terasa sulit karena didalamnya digunakan sistem matematika atau dengan kata lain siswa harus dapat berhitung 
sehingga fisika dianggap tidak menarik dan membosankan. Kenyataan ini adalah sebuah persepsi yang negatif terhadap fisika. Terhadap permasalahan tersebut maka telah dilakukan berbagai cara mengatasinya, salah satunya adalah membuat kondisi yang mendukung perkembangan kematangan siswa mempelajari fisika. Rendahnya keaktifan dan minat belajar siswa dalam proses pembelajaran fisika telah lama menjadi permasalahan dalam proses pembelajaran Telah berbagai strategi pembelajaran model kelompok diterapkan dan dilakukan, namun proses pembelajaran hanya didominasi oleh siswa yang pandai, sementara siswa yang berkemampuan rendah dan sedang tidak memperlihatkan partisipasinya dalam pembelajaran, sehingga tidak terjadi interaksi dalam pembelajaran, terutama interaksi antarasiswa dengan siswa.

Dalam kondisi seperti itu, tujuan pembelajaran model kelompok tidak terwujud karena siswa tidak mampu bekerja sama, tidak mampu menyampaikan pendapat dan menanggapi pendapat orang lain. Hal ini merupakan kegagalan guru dalam proses pembelajaran. Ada kecenderungan pembelajaran terpusat kepada guru (teacher centered). Tidak ada umpan balik (feedback)dari siswa sehingga proses pembelajaran tidakbermutu. Dengan demikian dapat dipastikan bahwa keterampilan proses sains tidak sesuai dengan harapan.

Keterampilan proses sains adalah seluruh keterampilan ilmiah yang dinggunakan untuk menemukan konsep atau prinsip atau teori dalam rangka mengembangkan konsep yang telah ada atau meyangkal penemuan sebelumnya (Najwatul IImi, dkk, 2016:58). Keterampilan proses sains meliputi keterampilan: mengobservasi, mengkomunikasikan, mengklasifikasi, mengukur, menyimpulkan, meramalkan, mengidentifikasi variabel, mengidentifikasi tabulasi, mengidentifikasi grafik, mendeskripsikan hubungan variabel, memperoleh dan memproses data, menganalisis penyelidikan, merumuskan hipotesis, melakukan percobaan.

Berdasarkan pemaparan diatas, maka peneliti tertarik untuk mengadakan "Pengembangan Kartu Pintar Fisika Untuk Meningkatkan Keterampilan Proses Sains". Peneliti tertarik mengangkat judul tersebut bertujuan untuk dapat meningkatkan keterampilan proses sains siswa. Kartu
Pintar didalamnya berisi cover, materi, percobaan sederhana, kata-kata motivasi dan soal. Kartu Pintar Fisika didesain dengan tampilan gambar dan warna yang menarik. Media kartu pintar sebelumnya sudah diterapkan oleh peneliti lain dalam jurnal Bambang Surahmadi dengan judul penerapan teknik bermain kartu pintar untuk Meningkatkan Motivasi Belajar dan Hasil Belajar IPA.

\section{METODE PENGEMBANGAN Model Pengembangan}

Jenis penelitian dalam penelitian ini adalah penelitian pengembangan (Research \& Develop). Research \& Developmentment adalah metode penelitian yang digunakkan untuk menghasilakan produk (sugiyono, 2013: 297). Produk yang dihasilkan dalam penelitian pengembangan ini adalah kartu pintar. Penelitian pengembangan merupakan kegiatan mengembangkan suatau produk baru atau menyempurnakan produk yang telah ada.

Suatu model dapat diartikan sebagai suatu representasi baik visual maupun verbal. Mode menyajikan sesuatu atau informasi yang kompleks atau rumit menjadi sesuatu yang lebih sederhana atau mudah. Dengan model, seseorang akan lebih memahami sesuatu daripada melalui penjelasan-penjelasan panjang. Suatu model dalam penelitian pengembangan dihadirkan dalam bagian prosedur pengembangan, yang biasanya mngikuti model pengembangan yang dianut oleh peneliti. Model juga dapat memberikan kerangka kerja untuk pengembangan teori dan penelitian. Dengan mengikuti model tertentu yang dianut oleh peneliti, maka akan diperoleh sejumlah masukan (input) guna dilakukan penyempurnaan produk yang dihasilkan, apakah berupa bahan ajar, media, atau produk-produk yang lain, (Setyosari, 2015:282).

Model pengembangan yang digunakan dalam penelitian ini adalah Dick \& Cary yaitu menggariskan langkahlangkah untuk menghasilkan produk berupa kartu pintar: (1) Analisis kebutuhan dan tujuan, (2) Analisis pembelajaran, (3) Analisis pembelajar (siswa) dan konteks, (4) Merumuskan tujuan performansi, (5) Mengembangkan instrumen,

Mengembangkan Strategi pembelajaran, (7) Mengembangkan dan memilih bahan pembelajaran, (8) Merancang dan melakukan evaluasi vormatif, 
Melakukan revisi dan, (10) Evaluasi sumatif, (Setyosari, 2015:284).

\section{Prosedur Pengembangan}

Penelitian ini dilakukan sebanyak dua tahap, untuk Tahap I dilakukan sampai validasi desain dan untuk Tahap II dilakukan sampai pada tahap uji coba produk karena keterbatasan waktu dan dana. Media dikatakan valid apabila telah divalidasi oleh ahli dan diuji keefektifannya oleh peneliti dengan adanya peningkatan keterampilan proses sains pada diri masing-masing siswa.

\section{Metode Penelitian Tahap I}

Potensi dan Masalah

Penelitian dapat berangkat dari potensi dan masalah yang ada. Potensi adalah sesuatu yang bila didayagunakan akan memiliki nilai tambah (Sugiyono, 2013: 409). Potensi yang ditemukan dalam penelitian ini adalah kartu dalam kegiatan pembelajaran. Masalah dalam penelitian ini adalah kurangnya keterampilan proses sains siswa kelas XI SMK Muhammadiyah Mataram terhadap mata pelajaran Fisika.

\section{Pengumpulan Data}

Langkah yang diambil setelah ditemukan potensi dan masalah dalam penelitian ini adalah mengumpulkan informasi. Informasi dapat dilakukan sebagai bahan untuk perencanaan produk tertentu. Pada penelitian ini, peneliti akan menghasilkan dan mengembangkan produk berupa Kartu Pintar Fisika. Berdasarkan hasil pengumpulan informasi yang telah dilakukan disekolah, ditemukan permasalahan adalah rendahnya keterampilan proses pada siswa. Pemicu salah satunya adalah kurangnya media pembelajaran. Oleh karena itu, peneliti akan mengembangkan media pembelajaran berupa Kartu Pintar Fisika yang menarik dan sangat praktis di gunakan.

\section{Desain Produk}

Desain produk dalam penelitian ini diwujudkan dalam bentuk gambar atau bagan. Dalam penelitian ini, komponen desain produk adalah:

1. Produk yang dikembangkan adalah Kartu Pintar Fisika didesain dengan tampilan cover, materi, percobaan sederhana, kata-kata motivasi dan soal.

2. Kartu Pintar Fisika dipadukan dengan warna dan gambar-gambar sesuai dengan isi materi dan percobaan sederhana.

3. Jenis tulisan dan ukuran tulisan Kartu Pintar Fisika jelas dibaca.

\section{Validasi Produk}

Validasi produk dapat dilakukan dengan cara menghadirkan beberapa pakar tenaga ahli yang sudah berpengalaman untuk menilai produk baru yang dirancang tersebut (Sugiyono, 2013:414). Validasi isi dilakukan oleh para ahli bidang studi, ahli pengukuran, dan pakar yang memiliki keahlian yang relevan dengan bidang kajiannya.

Kegiatan validasi isi ini akan dilakukan oleh ahli media pembelajaran dan ahli materi Fisika dengan cara mengisi instrumen berupa angket dan memberi kritik atau saran terhadap produk pengembangan. Validasi isi dilakukan agar mengetahui kelayakan isi produk yang dikembangkan. Validasi ahli pada pengembangan Kartu Pintar Fisika merupakan tiga orang dosen dan satu orang guru Fisika SMK Muhammadiyah Mataram. Kriteria dosen diantaranya minimal menempuh pendidikan S2 dan guru SMK Muhammadiyah Mataram minimal menempuh pendidikan S1 dan berpengalaman mengajar materi FISIKA.

\section{Instrumen Pengumpulan Data}

Instrumen penelitian digunakan untuk mengukur nilai variabel yangakan diteliti (Sugiyono, 2013:149). Instrumen penelitian adalah suatu alat yang digunakan untuk mengukur fenomena yang terjadi pada penilitian yang dilakukan. Secara spesifik fenomena yang terjadi ini disebut variable penelitian (Sugiyono, 2013:148). Kuisioner merupakan teknik pengumpulan data yang dilakukan dengan cara memberi seperangkat pertanyaan atau pernyataan tertulis kepada responden untuk menjawabnya (Sugiyono, 2013: 199) Angket validasi media pembelajaran memiliki gradulasi pernyataan sangat positif sampai sangat negatif yang digunakan untuk mengukur indikator program yang berkaitan dengan kriteria pendidikan, tampilan dan kualitas teknis.

Skala pengukuran yang digunakan untuk mengukur validasi produk adalah skala likert yang memiliki gradulasi penilaian dari sangat positif sampai sangat negatif. Teknik skorsing dalam skala likert adalah sebagai berikut:

Skala pengukuran yang digunakan untuk mengukur keterampilan proses sains adalah skala likert yang memiliki gradulasi

penilaian dari sangat positif sampai sangat negatif. Teknik skorsing dalam skala likert adalah sebagai berikut: 
1. Sangat Setuju (Sangat Positif) diberi skor 5

2. Setuju (Positif) diberi skor 4

3. Kurang Setuju (Negatif) diberi skor 3

4. Tidak Setuju (Sangat Negatif) diberi skor 2

5. Sangat Tidak Setuju (Sangat Negatif) diberi skor 1

Teknik Analisa Data

Analisa data dilakukan setelah

proses pengumpulan data, dimana penelitian ini lebih menitik beratkan pada pengembangan kartu pintar fisika pada materi kesetimbangan benda tegar. Angket yang digunakan harus dilakukan uji validasi Dimana teknik analisis data untuk percobaan ini adalah teknik angket. Angket diberikan kepada siswa mengenai produk atau media yang akan dikembangkan.

Metode Penelitian Tahap II

Rancangan Eksperimen Untuk Menguji Subjek Uji Coba

Uji coba produk merupakan bagian penting dalam penelitian pengembangan yang dilakukan setelah rancangan produk selesai. Uji coba produk yang dilakukan untuk mengetahui apakah Kartu Pintar Fisika yang dikembangkan dapat meningkatkan keterampilan proses sains siswa atau tidak dapat meningkatkan keterampilan proses sains siswa.

Subjek uji coba terdiri atas ahli bidang isi atau materi, ahli bidang perancangan produk dan sasaran pemakai produk. Dimana subjek uji coba untuk ahli materi dan perancangan atau media berfungsi sebagai validator yaitu dengan mengisi instrument berupa angket dan memberi kritik atau saran terhadap produk pengembangan. Validasi dilakukan agar mengetahui kelayakan isi produk yang dikembangkan.

\section{Populasi dan Sampel}

Penelitian ini dilaksanakan di SMK Muhammadiyah Mataram, penelitian ini menggunakan satu kelas sampel uji coba (One Group Pre-Test and Post-Test Design) kelas XI.TSM.

\section{Instrument Pengumpulan Data}

Instrument yang digunakan dalam

penelitian ini lembar observasi keterampilan proses sains. Lembar observasi adaah dasar semua ilmu pngetahuan, (Nasution, 1988 dalam (Sugiyono, 310:2013)).

Tekhnik Pengumpulan Data
Lembar observasi keterampilan proses sains digunakan untuk mengetahui besar peningkatan penggunaan media pembelajaran Kartu Pintar Fisika bila dibandingkan dengan media konvensional. Dibawah ini merupakan tabel kisi-kisi keterampilan proses sains.

Pengukuran yang digunakan untuk mengukur keterampilan proses sains adalah menggunakan lembar observasi guru dengan skor penilaian dari skala 1 sampai dengan skala 4.

Teknik Analisis Data Angket Validasi Produk

Teknik analisis data angket validasi produk pada penelitian ini dilakukan untuk mengetahui kelayakan produk yang dikembangkan sebelum digunakan. Dimana data yang diperoleh melalui penilaian ahli media atau praktisi kemudian

akan dijumlahkan dan total skor yang diperoleh dikonversikan menjadi data kualitatif dengan skala lima.

Tabel 1. Konversi Data Kuantitatif Ke Kualitatif Dengan Skala Lima

\begin{tabular}{|c|c|c|}
\hline Interval & Kriteria & Skor \\
\hline$(\mathrm{M}+1,50 \mathrm{~s})<\mathrm{X}$ & $\begin{array}{l}\text { Sangat } \\
\text { baik }\end{array}$ & $A$ \\
\hline $\begin{array}{l}(M+0,50 s)< \\
X \leq(M+ \\
1,50 s)\end{array}$ & Baik & $B$ \\
\hline $\begin{array}{l}(M-0,50 s)< \\
X \leq(M+ \\
0,50 s)\end{array}$ & $\begin{array}{l}\text { Cukup } \\
\text { baik }\end{array}$ & C \\
\hline $\begin{array}{l}(M-1,50 s)< \\
X \leq(M- \\
0,50 s)\end{array}$ & $\begin{array}{l}\text { Kurang } \\
\text { baik }\end{array}$ & $\bar{D}$ \\
\hline $\begin{array}{l}X \leq \\
1,50 s)\end{array}$ & Tidak baik & $E$ \\
\hline
\end{tabular}

Keterangan:

$\mathrm{X}=$ Total skor responden

$\mathrm{M}=$ Mean ideal, $1 / 2$ (skor maksimal ideal+skor minimal ideal)

$\mathrm{s}=$ Simpangan baku ideal, $1 / 6$ (skor maksimal ideal-skor minimal ideal)

\section{Teknik Analisis Data Keterampilan} Proses Sains

Analisis data dilakukan setelah proses pengumpulan data, dimana penelitian ini lebih menitik beratkan pada pengembangan kartu pintar fisika dalam meningkatkan keterampilan proses sains siswa kelas XI SMK.

\section{a. Uji Validitas}

Menurut Arikunto (2013:90) sebuah item dikatakan valid apabila 
mempunyai dukungan yang besar terhadap skor total menjadi tinggi atau rendah. Untuk mengetahui valid atau tidaknya soal dan angket dapat dihitung dengan korelasi product moment dengan menggunakkan rumus :

$$
r_{x y}=\frac{N \sum X Y-\left(\sum X\right)\left(\sum Y\right)}{\sqrt{\left\{N \sum X^{2}-\left(\sum X\right)^{2}\right\}\left\{N \sum Y^{2}-\left(\sum Y\right)^{2}\right\}}}
$$

Keterangan :

$$
\begin{aligned}
& r_{x y}=\text { koefisien korelasi product } \\
& \text { moment } \\
& \sum X=\text { Jumlah skor butir soal atau } \\
& \text { angket } \\
& \sum Y=\text { Jumlah skor total } \\
& N \quad=\text { Jumlah responden } \\
& \sum X^{2}=\text { Jumlah kuadrat skor butir soal } \\
& \text { atau observasi } \\
& \sum Y^{2}=\text { Jumlah kuadrat skor total soal } \\
& \text { atau Observasi } \\
& \sum X Y=\text { Jumlah hasil kali skor butir }
\end{aligned}
$$

soal atau observasi (Arikunto, 2013:87)

Uji signifikansi korelasi product moment dikonsultasikan pada $r$ tabel product moment dengan taraf kesalahan $5 \%$. Apabila $r$ hitung lebih besar dari $r$ tabel maka soalnya valid, tetapi jika $r$ hitungnya lebh kecil dari $r$ tabel maka soalnya tidak valid (Sugiyono, 2013:258).

\section{b. Uji Reliabilitas}

Uji reliabilitas dilakukan untuk mengetahui reliabilitas soal dan angket, (instrument) yang digunakan. Langkahlangkah mencari nilai reliabilitas sebagai berikut:

$$
r_{11}=\left(\frac{n}{n-1}\right)\left(1-\frac{\sum \sigma_{i}^{2}}{\sigma_{t}^{2}}\right)
$$

Keterangan:

$$
\begin{aligned}
& r_{11}=\text { Nilai reliabilitas } \\
& \sum \sigma_{t}^{2}=\text { Jumlah varians skor tiap- }
\end{aligned}
$$

tiap item

$$
\begin{gathered}
\sigma_{t}^{2}=\text { Varians total } \\
n=\text { Banyak item }
\end{gathered}
$$

Selain itu perlu dicari nilai varians untuk menentukan reliabilitas soal dan angket menggunakan rumus sebagai berikut:

$$
\sigma_{t}^{2}=\frac{\sum X^{2}-\frac{\left(\sum X\right)^{2}}{N}}{N}
$$

Keterangan:

$\sigma_{t}^{2}=$ Varians skor tiap-tiap item

$\sum X^{2}=$ Jumlah kuadrat skor total

$\left(\sum X\right)^{2}=$ Jumlah skor total yang dikuadratkan

$\mathrm{N}=$ Jumlah responden (Arikunto, 2013:112-115)

Nilai korelasi yang diperoleh dikonsultasikan ke tabel Product Moment dengan taraf $a=0,05$ atau $a=0,01$. Jika harga $r_{\text {hitung }}>r_{\text {tabel }}$ maka reliabilitas dan harga $r_{\text {hitung }}<r_{\text {tabel }}$ berarti tidak reliabilitas, (Arikunto, 2013:125).

\section{c. Keterampilan Proses Sains}

Menghitung besarnya peningkatan keterampilan proses sains siswa dengan menggunakan rumus Hake:

$$
\text { gain }=\frac{S_{\text {post }}-S_{\text {pre }}}{100-S_{\text {pre }}}
$$

$$
\begin{aligned}
& \text { Keterangan: } \\
& \text { g(gain) = gain } \\
& S_{\text {pre }}=\text { skor awal } \\
& \text { Spost }_{\text {p }} \text { skor akhir }
\end{aligned}
$$

Data hasil perhitungan keterampilan proses sains sebelum dan sesudah siswa kemudian akan diiterpretasikan dengan menggunakan gain standar sebagai berikut :

Tabel 2. Nilai Indeks Gain Standar

\begin{tabular}{|c|c|}
\hline $\begin{array}{l}\text { Nilai } \\
\text { gain } \\
\text { standar }\end{array}$ & $\begin{array}{l}\text { Keteranga } \\
\mathrm{n}\end{array}$ \\
\hline$\geq 0,7$ & Tinggi \\
\hline $\begin{array}{c}0,7 \geq g \\
\geq 0,3\end{array}$ & Sedang \\
\hline$\leq 0,3$ & Rendah \\
\hline
\end{tabular}

(Hake, 1998: 65)

Apabila media pembelajaran dapat meningkatkan keterampilan proses sains siswa, maka media pembelajaran dikatakan telah teruji keefektifannya.

d. Pengaruh Keterampilan Proses Sains Siswa

Untuk menentukan pengaruh keterampilan proses sains siswa terhadapa KARTU PINTAR terlebih ahulu dihitung nilai Chi Kuadrat. 


$$
\chi^{2}=\sum_{i=1}^{k} \frac{\left(f_{0}-f_{h}\right)}{f_{h}}
$$

Keterangan :

$$
\begin{aligned}
& \chi^{2}=\text { Chi Kuadrat } \\
& f_{0}=\text { Frekuensiyang diobservas } \\
& f_{h}=\text { frekuensiyang diharapkan }
\end{aligned}
$$

\section{HASIL DAN PEMBAHASAN \\ Hasil Penelitian \\ Metode Penelitian Tahap I}

Potensi dan Masalah

Berdasarkan hasil wawancara dengan guru fisika di SMK Muhammadiyah Mataram, ditemukan adanya potensi yang dimiliki oleh siswa untuk melakukan praktikum pada mata pelajaran fisika akan tetapi adanya permasalahan yang mengakibatkan kurangnya keterampilan proses sains yaitu metode pengajaran yang digunakkan oleh guru kurang efektif, kurangnya menggunakan media pembelajaran sebagai media tambahan untuk menarik minat belajar siswa, dan tidak tersedianya buku pelajaran serta tidak adanya paraktikum bagi masingmasing siswa.

Oleh karena tidak tersedianya buku pelajaran dan paraktikum bagi masing-masing siswa sehingga pada setiap pelajaran fisika wajib mencatat untuk mengejar materi tanpa adanya praktikum. Permasalahan tersebut harus diatasi dan diperlukan suatu cara, bukan hanya strategi dan model pembelajaran yang cocok digunakan oleh guru selama proses pembelajran, namun yang paling penting adalah media pembelajaran tambahan dan praktikum yang dapat membatu siswa dalam belajar sehingga tidak perlu mencatat semua materi setiap pertemuan. Salah satu media pembelajaran yang tepat dan sesuai untuk meningkatkan keterampilan proses sains siswa adalah KARTU PINTAR.

\section{Mengumpulkan Informasi}

Pengumpulan informasi dilakukan dengan observasi dan wawancara sehingga diperoleh informasi bahwa keterampilan proses sains kelas XI di SMK Muhammadiyah Mataram masih kurang. Observasi dilakukan dengan menanyakan permasalahan pada guru yang mengajar dan melakukan pengamatan dalam kegiatan pembelajaran dikelas. Pada saat observasi dilakukan siswa cenderung hanya mencatat dan menghafal sedangkan pada mata pelajaran fisika diperlukan adanya praktikum. Berdasarkan hasil wawancara pada guru mata pelajaran fisika SMK Muhammadiyah Mataram mengatakan siswa membutuhkan adanya media tambahan untuk menumbuhkan minat belajar siswa terutama pada mata pelajaran fisika karena selama ini siswa hanya cenderung mencatat dan menghafal tanpa pernah melakukan praktikum.

\section{Desain Produk}

Berdasarkan kondisi yang telah ada di sekolah, dapat diketahui bahwa dalam pelaksanaan pembelajaran media buku yang praktis dan praktikum sangat dibutuhkan oleh siswa. Buku pelajaran disekolah yang digunakan guru untuk mengajar masih kurang membantu untuk meningkatkan keterampilan proses sains siswa. Buku pelajaran yang digunakan dalam pembelajaran memiliki pembahasan materi yang panjang sehingga siswa cepat merasa bosan dalam membacanya kemudian sulit memahami konsep dalam buku tersebut. Serta buku pelajaran yang digunakan tersebut tidak memiliki praktikum yang bertujuan untuk meningkatkan keterampilan proses sains siswa. Dengan demikian, maka diperlukan media yang mampu menigkatkan keterampilan proses sains siswa.

Berdasarkan kondisi yang telah ada di sekolah, peneliti mengembangkan KARTU PINTAR yang terdiri dari kover KARTU PINTAR, materi singkat, kegiatan praktikum, soal dan kata motivasi. KARTU PINTAR yang dibuat memiliki jenis dan ukuran tulisan yang mudah dibaca. Desain awal produk dikerjakan dengan menggunakan program microsoft office publizer 2007 kemudian dicetak dengan menggunakan kertas foto $A 4230 \mathrm{gram}$.

\section{Hasil Validasi Ahli}

Kegiatan validasi KARTU PINTAR dilakukan oleh para ahli dengan mengisi angket yang berisi 23 pernyataan yang terdiri dari kriteria pendidikan, kriteria tampilan, dan kualitas teknis. KARTU PINTAR divalidasi oleh 4 ahli yang dianggap respresentatif dan berpengalaman mengajar materi Fisika dan Ahli media. Angket diisi oleh ahli yang terdiri dari 3 orang dosen dan 1 guru mata pelajaran FISIKA di SMK Muhammadiyah Mataram. Hasil validasi KARTU PINTAR adalah sebagai berikut:

\section{Ahli I}

Sesuai dengan hasil pengisian angket dari Bapak Zulkarnain M.Si selaku ahli I, dari hasil pengolahan data 
menggunakan interval diperoleh untuk kualitas kriteria pendidikan dengan jumlah 6 pernyataan didapat skor 27 dengan rentang nilai interval $A$ (sangat baik), untuk kriteria tampilan ada 8 pernyataan diperoleh skor 31 dengan rentang nilai interval B (baik). Untuk kriteria pendidikan terdapat 9 pernyataan didapat skor 40 dengan rentang nilai interval $A$ (sangat baik), sehingga disimpulkan bahwa KARTU PINTAR layak untuk digunakan dan ahli I menyarankan revisi pada warna, background dan jangan gunakan gambar hitam putih.

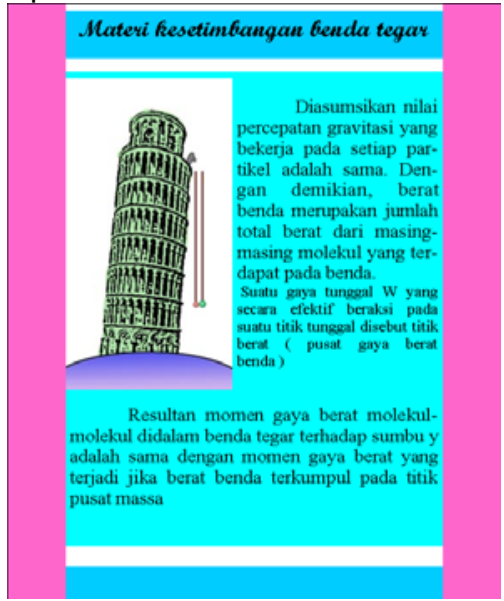

Gambar 1. revisi warna gambar

Ahli II

Pengisian angket dari Bapak Islahudin, M.Pfis selaku ahli II, pada kriteria pendidikan dengan 6 pernyataan diperoleh skor 22 dengan nilai interval B (baik), sedangkan pada kriteria tampilan dengan 8 pernyataan diperoleh skor 30 dengan nilai interval B (baik). Dan pada kriteria teknis dengan 9 pernyataan diperoleh skor 34 dengan nilai interval $B$ (baik). Adapun revisi dari Ahli II yaitu pada daftar pustaka, gambar cover, dan warna gambar.

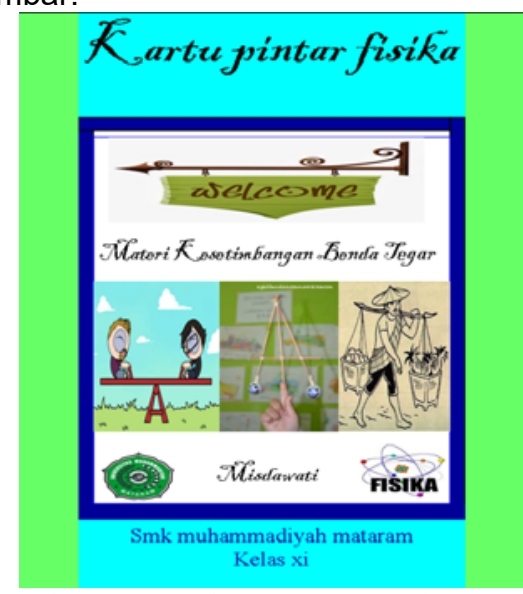

Gambar 2 Gambar Pada Cover
Ahli III

Pengisian angket dari Ibu Linda Sekar Utami, M.Pfis selaku ahli III pada kriteria pendidikan dengan 6 pernyataan diperoleh skor 26 dengan nilai interval $A$ (sangat baik), sedangkan pada kriteria tampilan dengan 8 pernyataan diperoleh skor 29 dengan nilai interval B (baik). Dan pada kriteria teknis dengan 9 pernyataan diperoleh skor 37 dengan nilai interval $A$ (sangat baik).. Ahli III merekomendasikan perbaikkan revisi pada bagian gambar cover, background, warna, bedakan alat dan bahan, data yang dianalisis.

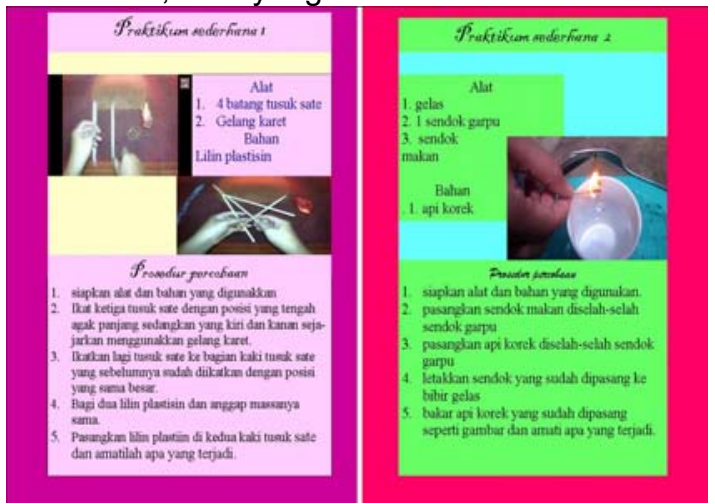

Gambar 3. pergantian warna pada setiap KARPIN dan warna font yang jelas dibaca

\section{Praktisi}

Hasil pengisian angket dari lbu Nora Yuliza L, S.Pd selaku praktisi pada kriteria pendidikan diperoleh skor 24 dengan interval nilai B (baik), sedangkan pada kriteria tampilan diperoleh skor 32 dengan interval nilai $A$ (sangat baik), dan pada kriteria teknis diperoleh skor 35 dengan interval nilai $B$ (baik). praktisi merekomendasikan media pembelajaran KARPIN tidak hanya digunakan pada mata pelajaran fisika saja.

Persentase hasil perhitugan validasi media Ahli I, Ahli II, Ahli III, dan Praktisi.

\section{VALIDASI PRODUK}

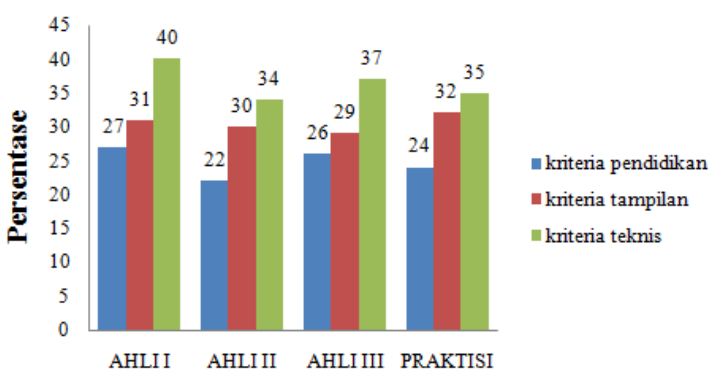

Grafik 4. Persentase Validasi Produk 


\section{Revisi Produk}

Hasil validasi produk yang telah dilakukan menunjukkan bahwa KARTU PINTAR harus dilakukan revisi pada bagian tertentu yaitu proporsional gambar, warna tulisan, background dan logo institusi pada cover, untuk lebih jelasnya lihat pada lampiran 4

\section{Metode Penelitian Tahap II}

Hasil Uji Lembar Observasi Guru

Media pembelajaran KARTU

PINTAR ini selanjutnya diterapkan untuk meningkatkan keterampilan proses sains siswa pada kelompok kecil yaitu kelas XI.TSM SMK Muhammadiyah Mataram. Besar keterampilan proses sains siswa dapat diukur dengan memberikan lembar observasi keterampilan proses sains kepada siswa. Ada beberapa bentuk aspek keterampilan proses sains siswa yang ingin diketahui dalam penelitian ini antara lain, pengamatan atau observasi, mengajukan pertanyaan, melakukan eksperimen, mengasosiasikan, dan berkomunikasi. Hasil uji lembar observasi keterampilan proses sains sebagai berikut :

Tabel 5. Hasil Perhitungan Persentase Lembar Observasi

\begin{tabular}{|c|l|c|c|}
\hline $\begin{array}{c}\mathrm{N} \\
\mathrm{O} \\
.\end{array}$ & Indicator & $\begin{array}{c}\text { Persentas } \\
\text { e sebelum } \\
(\%)\end{array}$ & $\begin{array}{c}\text { Persentas } \\
\text { e sesudah } \\
(\%)\end{array}$ \\
\hline 1 & $\begin{array}{l}\text { Pengamata } \\
\text { n/observasi }\end{array}$ & 63 & 83 \\
\hline 2 & $\begin{array}{l}\text { Mengajukan } \\
\text { pertanyaan }\end{array}$ & 67 & 82 \\
\hline 3 & $\begin{array}{l}\text { Melakukan } \\
\text { eksperimen }\end{array}$ & 68 & 82 \\
\hline 4 & $\begin{array}{l}\text { Mengasosia } \\
\text { sikan }\end{array}$ & 66 & 79 \\
\hline 5 & $\begin{array}{l}\text { Berkomunik } \\
\text { asi }\end{array}$ & 61 & 82 \\
\hline
\end{tabular}

Pengolahan lembar observasi keterampilan proses sains siswa selengkapnya dapat dilihat pada lampiran 10.

\section{Hasil Uji Validitas Lembar Uji Coba Observasi}

Untuk mengukur keterampilan proses sains siswa dilakukan uji validitas pada lembar uji coba observasi dengan menggunakan persamaan korelasi product moment. Hasil uji validitas lembar uji coba observasir keterampilan proses sains adalah sebagai berikut:
Tabel 6. Hasil Perhitungan Validitas Pernyataan Angket

\begin{tabular}{|c|c|c|}
\hline Jumlah Item & Valid & Tidak Valid \\
\hline 13 & 7 & 5 \\
\hline
\end{tabular}

\section{Hasil Uji Validitas Lembar Uji Coba Observasi}

Uji coba reliabilitas lembar uji coba observasi dilakukan pada 13 item dengan menggunakan ritung diperoleh nilai sebesar 0,786 dan nilai $r_{\text {tabel }}$ pada taraf signifikan $5 \%$ dengan $\mathrm{N}=15$ diperoleh nilai 0,514 . Terlihat bahwa $r_{\text {hitung }}$ lebih besar dari $r_{\text {tabel }}$ yaitu $(0,768>0,514) \quad$ maka instrument penelitian dikatakan reliable. Pengolahan reliabilitas pernyataan pada lembar uji coba observasi keterampilan proses sains siswa selengkapnya dapat dilihat pada lampiran 9.

Hasil Uji Coba

Uji kelompok yang digunakan adalah kelas XI.TSM SMK Muhammadiyah Mataram dengan menggunakan lembar observasi keterampilan proses sains yang sudah valid. Kemudian dilakukan pembelajaran menggunakan buku biasa setelah itu diberikan lembar observasi kepada 3 observer. Kegiatan pengisian lembar obervasi dapat dilakukan selama pembelajaran berlangsung. Masingmasing siswa mendapatkan 1 praktikum dimana 1 kelompok terdiri dari 2 sampai 3 orang.

Perhitungan keterampilan proses sains siswa dilakukan pada setiap bentuk aspek atau indikator keterampilan proses sains. Hasil lembar observasi keterampilan proses sains kemudian diolah dengan menggunakan langkah-langkah yang dilakukan dapat dilihat pada lampiran 10 . Berdasarkan hasil perhitungan dalam penelitian yang dilakukan, maka dapat dilihat peningkatan keterampilan proses sains pada siswa.

Persentase hasil perhitungan keterampilan proses sains siswa tiap indikator sebelum menggunakan KARTU PINTAR dan setelah menggunakan KARTU PINTAR dapat dilihat pada grafik berikut ini: 
Grafik Keterampilan Proses Sains

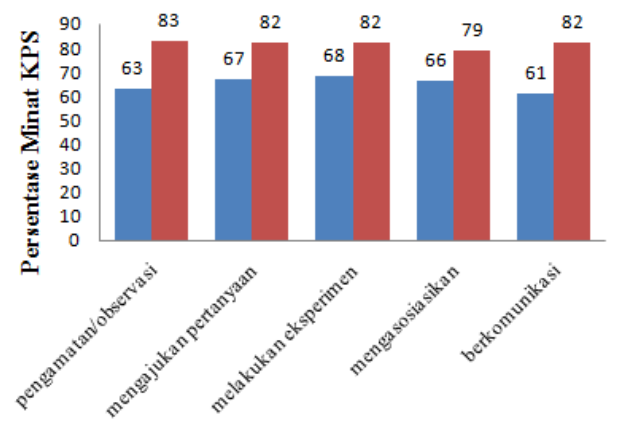

Indikator Keterampilan Proses Sains

Grafik 5. Persentase Keterampilan Proses Sains Setiap Indicator Sebelum dan Sesudah

Hasil perhitungan keterampilan proses sains siswa secara jelas dapat dilihat pada lampiran 10. Peningkatan keterampilan proses sains siswa juga harus dilihat secara klasikal. Dari hasil perhitungan dengan konversi data, diperoleh keterampilan proses sains siswa seperti pada kedua tabel berikut ini.

Tabel 7. Kelompok tingkat keterampilan proses sains siswa menggunakan media Konvensional

\begin{tabular}{|c|c|c|c|}
\hline No & Interval & $\begin{array}{c}\text { Jumlah } \\
\text { Siswa }\end{array}$ & $\begin{array}{c}\text { Tingkat } \\
\text { KPS }\end{array}$ \\
\hline 1 & $80-100$ & 0 & $\begin{array}{c}\text { Baik } \\
\text { sekali }\end{array}$ \\
\hline 2 & $66-79$ & 8 & Baik \\
\hline 3 & $56-65$ & 9 & Cukup \\
\hline 4 & $40-55$ & 0 & Kurang \\
\hline 5 & $30-39$ & & Gagal \\
\hline
\end{tabular}

Tabel 8. Kelompok tingkat keterampilan proses sains siswa menggunkan KARTU PINTAR

\begin{tabular}{|c|c|c|c|}
\hline No & Interval & $\begin{array}{c}\text { Jumlah } \\
\text { siswa }\end{array}$ & $\begin{array}{c}\text { Tingkat } \\
\text { KPS }\end{array}$ \\
\hline 1 & $80-100$ & 13 & $\begin{array}{c}\text { Baik } \\
\text { sekali }\end{array}$ \\
\hline 2 & $66-79$ & 8 & Baik \\
\hline 3 & $56-65$ & 0 & Cukup \\
\hline 4 & $40-55$ & 0 & Kurang \\
\hline 5 & $30-39$ & 0 & Gagal \\
\hline \multicolumn{3}{|c|}{$\begin{array}{c}\text { Secara klasikal, keterampilan } \\
\text { siswa mengalami }\end{array}$} \\
proses sains keningkatan. Peningkatan keterampilan \\
pentan
\end{tabular}

proses sains secara jelas terlihat pada tabel 7 dan tabel 8 Melalui perhitungan juga di buktikan bahwa persentase keterampilan proses sains siswa menggunakan media konvensional adalah sebanyak $65 \%$. Setelah penggunaan KARTU PINTAR persentase keterampilan proses sains siswa mengalami peningkatan menjadi $82 \%$. Besar peningkatan keterampilan proses sains dengan normalisasi nilai gain adalah 0,48 dimana peningkatan keterampilan proses sains siswa berada dalam kriteria sedang. Persentase peningkatan keterampilan proses sains siswa dapat dilihat pada grafik berikut ini:

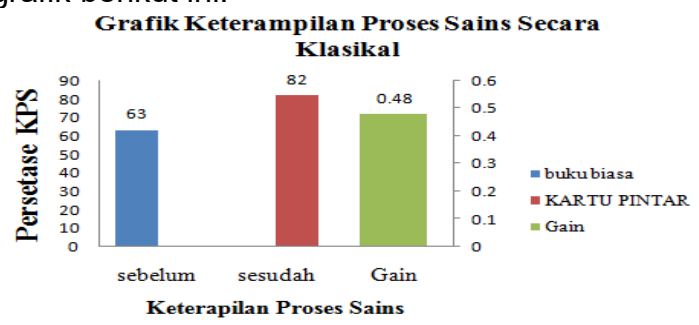

Grafik 6. Persentase Peningkatan Keterampilan Proses Sains Dengan menggunakan nilai $\mathrm{Chi}$ Kuadrat dikatakan ada pengaruh penerapan KARTU PINTAR terhadap peningkatan keterampilan proses sains masing-masing siswa. Berdasarkan taraf kesalahan 5\% dari jumlah 17 siswa, maka diperoleh harga Chi Kuadrat Tabel $=27,587$. Ternyata harga Chi Kuadrat hitung lebih besar dari Harga Chi Kuadrat tabel yaitu $(649>27,587)$. Ini berarti media pembelajaran KARTU PINTAR berpengaruh dalam meningkatkan keterampilan proses sains masing-masing siswa.

Tabel 9. Hasil Perhitungan Chi Kuadrat

\begin{tabular}{|c|c|}
\hline $\begin{array}{c}\text { Chi } \\
\text { Kuadrat }_{\text {hitung }}\end{array}$ & $\begin{array}{c}\text { Chi } \\
\text { Kuadrattabel }^{-}\end{array}$ \\
\hline 649 & 27,587 \\
\hline
\end{tabular}

\section{Pembahasan}

Dari hasil dari kegiatan observasi yang dilakukan terhadap siswa kelas XI.TSM SMK Muhamadiyah Mataram menunjukan bahwa potensi yang ditemukan dalam penelitian ini adalah adalah Buku pelajaran sebagai pegangan siswa untuk belajar dirumah dan didalam kelas selama kegiatan pembelajaran dengan masalah yang paling utama adalah kurangnya minat dan keterampilan proses sains siswa kelas $\mathrm{XI}$ SMK Muhammadiyah Mataram mata pelajaran Fisika. Rendahnya keterampilan proses sains siswa ini ditunjukan dengan 
jarangnya siswa mengajukan pertanyaan, malasnya siswa mencatat materi pelajaran dan kurangnya respon terhadap pertanyaan yang disampaikan oleh guru. Salah satu penyebabnya adalah tidak adanya buku pegangan siswa untuk belajar di rumah dan siswa harus mencatat dan memfoto copy materi untuk proses belajar mengajar dikelas tanpa melakukan praktikum.

Berdasarkan potensi yang ditemukan ini, peneliti bermaksud mengembangkan media berupa KARTU PINTAR. KARTU PINTAR pernah diterapkan disekolah lain tapi belum pernah dikembangkan di SMK Muhammadiyah Mataram. Media pembelajaran KARTU PINTAR yang akan dihasilkan yaitu terdiri dari cover KARTU PINTAR, materi pembelajaran, kegiatan praktikum, contoh soal dan kata-kata motivasi. KARTU PINTAR yang dibuat memiliki jenis dan ukuran tulisan yang mudah dibaca. Desain awal produk dikerjakan dengan menggunakan program microsoft office publizer 2007 kemudian dicetak dengan menggunakan kertas foto A4 230 gram untuk mengukur keterampilan proses sains.

Kondisi pada potensi dan masalah yang ada mendorong peneliti untuk mengembangkan KARTU PINTAR untuk membantu proses belajar mengajar. KARTU PINTAR memiliki kelebihan antara lain dapat meningkatkan keterampilan proses sains siswa dalam proses pembelajaran. Selain itu juga KARTU PINTAR ini memiliki kombinasi warna yang bervariasi dan gambar-gambar menarik minat baca pada siswa.

KARTU PINTAR yang akan dihasilkan yaitu terdiri dari cover KARTU PINTAR, materi pembelajaran, kegiatan praktikum, soal dan kata-kata motivasi. KARTU PINTAR yang dibuat memiliki jenis dan ukuran tulisan yang mudah dibaca. Desain awal produk dikerjakan dengan menggunakan program microsoft office publizer 2007 kemudian dicetak dengan menggunakan kertas foto A4 230 gram.

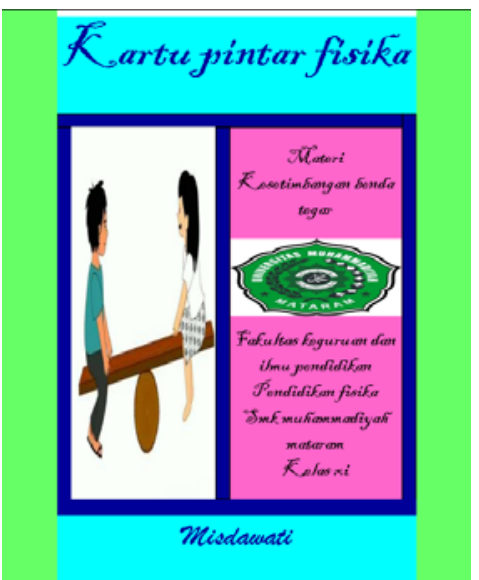

Gambar 7. cover belum revisi

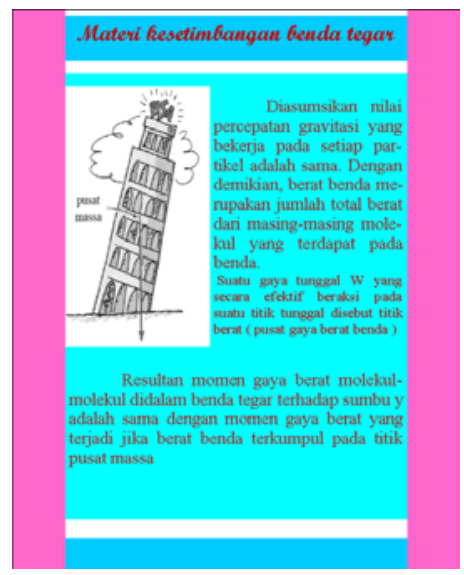

Gambar 8. Belum Revisi

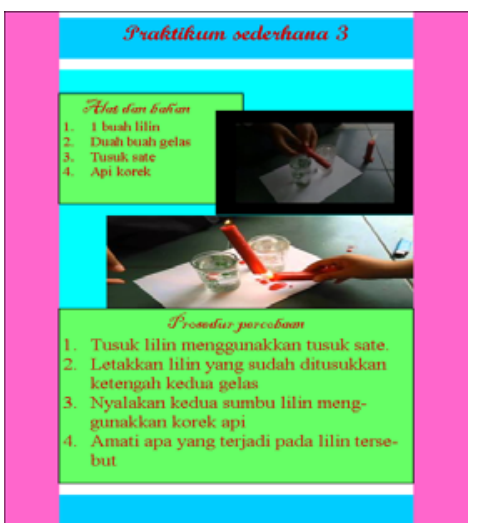

Gambar 9. Warna Belum Revisi

Media pembelajaran yang telah di desain divalidasi oleh ahli sebelum diuji pada kelompok kecil. Validasi KARTU PINTAR dilakukan oleh 3 ahli 1 praktisi. Hasil validasi dari ahli praktisi mengatakan tidak ada revisi terhadap produk karena sudah dikatakan layak untuk digunakan. Hasil yang berbeda diperoleh dari ahli I,II dan III merekomendasikan perbaikkan mengenai warna tulisan, warna gambar, 
daftar pustaka, kover, dan logo, untuk lebih jelasnya lihat lampiran 4.

Diperoleh peningkatan untuk keterampilan proses sains berupa pengamatan atau observasi $83 \%$. dengan kriteria cukup baik, keterampilan proses sains berupa mengajukan pertanyaan $82 \%$ dengan kriteria cukup baik, keterampilan proses sains berupa melakukan eksperimen $82 \%$ dengan kriteria baik, keterampilan proses sains berupa mengasosiasikan $79 \%$ dengan kriteria baik dan yang terakhir keterampilan proses sains berupa berkomunikasi $82 \%$ dengan kriteria baik. Sedangkan Peningkatan keterampilan proses sains secara klasikal juga berada pada kriteria sedang dengan normalisasi gain sebesar 0,48 . Berdasarkan taraf kesalahan $5 \%$ dari jumlah 17 siswa, maka diperoleh harga Chi Kuadrat Tabel $=27,587$. Ternyata harga Chi Kuadrat hitung lebih besar dari Harga Chi Kuadrat tabel yaitu (649>27,587). Ini berarti media pembelajaran KARTU PINTAR efektif dalam meningkatkan keterampilan proses sains masing-masing siswa.

Hasil pengisian dari Ibu Nora Yuliza L, S.Pd selaku praktisi bahwa pengisian angket terendah berada pada skala 3 (kurang setuju) yaitu item 3 dikriteria teknis pada nomor item 6 dengan pernyataan pengembangan media pembelajaran KARPIN hanya dapat digunakan pada matapelajaran fisika saja. Pada kriteria teknis diperoleh skor 35 dengan nilai interval B (baik). Berdasarkan skor yang didapatkan KARPIN praktis digunakan dalam mata pelajaran apapun.

\section{KESIMPULAN DAN SARAN \\ Kesimpulan}

Berdasarkan penelitian yang telah dilaksanakan dapat disimpulkan bahwa KARTU PINTAR dapat:

1. Teruji keefektifannya karena mampu meningkatkan keterampilan proses sains siswa kelas X.TSM SMK Muhammadiyah Mataram pada materi kesetimbangan benda tegar. Dimana diperoleh peningkatan untuk keterampilan proses sains berupa pengamatan atau observasi $83 \%$. dengan kriteria cukup baik, keterampilan proses sains berupa mengajukan pertanyaan $82 \%$ dengan kriteria cukup baik, keterampilan proses sains berupa melakukan eksperimen $82 \%$ dengan kriteria baik, keterampilan proses sains berupa mengasosiasikan $79 \%$ dengan kriteria baik dan yang terakhir keterampilan proses sains berupa berkomunikasi $82 \%$ dengan kriteria baik. Sedangkan Peningkatan keterampilan proses sains secara klasikal juga berada pada kriteria sedang dengan normalisasi gain sebesar 0,48 . Berdasarkan taraf kesalahan 5\% dari jumlah 17 siswa, maka diperoleh harga Chi Kuadrat Tabel $=27,587$. Ternyata harga Chi Kuadrat hitung lebih besar dari Harga Chi Kuadrat tabel yaitu (649>27,587). Ini berarti media pembelajaran KARTU PINTAR berpengaruh dalam meningkatkan keterampilan proses sains masing-masing siswa.

2. Teruji kevalidannya baik dari segi ahli media maupun materi, dimana untuk kriteria pendidikan 2 ahli memberikan nilai $A$ dan 2 ahli memberikan nilai $B$, untuk kriteria tampilan 3 ahli memberikan nilai $B$ dan nilai $A$ dari 1 ahli yang lain, serta untuk kriteria teknis 2 ahli memberikan nilai $A$ dan 2 ahli memberikan nilai $B$.

3. Teruji kepraktisannya dengan Hasil pengisian dari praktisi bahwa pengisian angket terendah berada pada skala 3 (kurang setuju) yaitu item 3 dikriteria teknis pada nomor item 6 dengan pernyataan pengembangan media pembelajaran KARPIN hanya dapat digunakan pada matapelajaran fisika saja. Pada kriteria teknis diperoleh skor 35 dengan nilai interval B (baik). Berdasarkan skor yang didapatkan KARPIN praktis digunakan dalam mata pelajaran apapun..

\section{Saran}

Berdasarkan penelitiaan yang telah dilakukan, maka diberikan beberapa saran bagi peneliti selanjutnya yaitu:

1. KARTU PINTAR yang dikembangkan dapat digunakan dengan baik, namun masih memiliki kekurangan baik dari segi pendidikan, tampilan, dan kualitas teknis. Hal ini dapat dijadikan pertimbangan bagi peneliti selanjutnya untuk mengembangkan media pembelajaran yang lebih sempurna lagi.

2. KARTU PINTAR dapat dikembangkan untuk semua materi Fisika dan untuk mata pelajaran lain.

3. Penelitian ini dilaksanakan sampai pada tahap uji coba kelompok kecil. Oleh karena itu diharapkan pada penelitian selanjutnya dilaksanakan sampai pada tahap penyebaran. 
Volume 3, Nomor 2, November 2017 p-ISSN : 2460-9587 e-ISSN : 2614-7017

\section{DAFTAR PUSTAKA}

Arikunto, Suharsimi, 2013. Dasar-Dasar Evaluasi Pendidikan. Jakarta: Bumi Aksara

Arsyad, Azhar, 2015. Media Pembelajaran. Depok: PT Rajagrafindo Persada

Azizahwati, dkk. Pengembangan Modul Pembelajaran Fisika SMA Berbasis Kearifan Lokal untuk Meningkatkan Hasil Belajar Siswa. Jurnal Prosiding Pertemuan IImiah XXIX HFI. ISSN : 0853-0823

Baiq Ewik Jiniarti, dkk. Implementasi Model Problem Based Learning Berbantuan Alat Peraga Untuk Meningkatkan Aktivitas dan Hasil Belajar Fisika Siswa Kelas VIII SMPN 22 Mataram Tahun Pelajaran 2014/2015. Jurnal Pendidikan Fisika dan Teknologi Volume I No 3 ISSN. 2407-6902

Daryanto, 2015. Media Pembelajaran. Bandung: PT. Sarana Tutorial Nurani Sejahtera

Dian Hardianti, dkk. Perbedaan Hasil Belajar Fisika Siswa Untuk Model Pembelajaran Berbasis Proyek Dengan Model Pembelajaran Langsung Pada Kelas $X$ SMA Negeri 7 Palu. Jurnal Pendidikan Fisika Tadulako (JPFT) Vol. 4 No. 2. ISSN 23383240

Dedy Hamdani, dkk. Pengaruh Model Pembelajaran Generatif Dengan Menggunakan Alat Peraga Terhadap Pemahaman Konsep Cahaya Kelas VIII di SMP Negeri 7 Kota Bengkulu. Jurnal Exacta, Vol. X No. 1. ISSN 1412-3617

E-Jurnal Dinas Pendidikan Kota Surabaya; Volume 5 ISSN : 2337-3253

Giancoli, 2001. Fisika Edisi Kelima Jilid 1. Jakarta: PT. Gelora Aksara Pratama

Halliday David, 2003. Dasar-Dasar Fisika jilid I. Tanggerang: Binarupa Aksara Publisher.

Riduwan, 2014. Metode dan Teknik Menyusun Proposal Penelitian. Bandung: Alvebeta. Cv

Sudjana, Nana, 2014. Penelitian dan Penilaian Pendidikan. Bandung: Sinar Baru Algensindo

Sugiyono, 2013. Metode Penelitian Pendidikan Pendekatan Kuantitatif, Kualitatif dan R\&D. Bandung: Alvabeta. Cv
Sugiyono, 2015. Metode Penelitian Pendidikan Pendekatan Kuantitatif, Kualitatif dan R\&D. Bandung: Alvabeta. Cv

Suherman, dkk. IbM Perangkat Pembelajaran Berbasis Budaya Sunda Untuk Guru-Guru Mipa Smp Di Kecamatan Karangnunggal Tasikmalaya. Jurnal Siliwonsi Vol.2 No.1. ISSN 2477-6629

Yusuf, Muri, 2015. Asesmen Dan Evaluasi Pendidikan. Jakarta: Prenadamedia Group 